Deteksi Virus Pada Udang Vaname (Litopenaeus vannamei) di Balai Karantina Ikan, Pengendalian Mutu, dan Keamanan Hasil Perikanan Surabaya I

\title{
Virus Detection of Pacific White Shrimp (Litopenaeus vannamei) at Fish Quarantine Center, Quality Control, and Security of Fishery Product in Surabaya I
}

\author{
Aulia A.M.S ${ }^{1 *}$, D.S. Budi ${ }^{2}$, A.H. Fasya ${ }^{2}$, H. Kenconojati ${ }^{2}$, M.H. Azhar ${ }^{2}$ \\ ${ }^{1}$ Mahasiswa Program Studi Akuakultur PSDKU Universitas Airlangga di Banyuwangi \\ ${ }^{2}$ Dosen Program Studi Akuakultur, Fakultas Perikanan dan Kelautan, Universitas Airlangga \\ PSDKU Banyuwangi \\ Jl. Wijaya Kusuma No. 133, Banyuwangi 68425, Indonesia *Email: rustriy@ yahoo.com \\ *Email: aulia.azizah-2016@fpk.unair.ac.id
}

\begin{abstract}
Abstrak
Udang vaname memiliki beberapa keunggulan yaitu pertumbuhan yang cepat, mampu beradaptasi pada kisaran salinitas yang tinggi, dan dapat dipelihara dengan sistem super intensif, namun beberapa tahun terakhir total produksi udang di Indonesia mengalami penurunan. Tahun 2012 total produksi udang menururn dari 1.900 ton menjadi 1.025 ton, virus diduga menjadi patogen yang memicu penyakit pada udang dan menyebabkan mortalitas yang tinggi. Tujuan penelitian ini yaitu untuk mendeteksi virus pada udang vaname dan mengetahui tingkat prevalensi virus yang menyerang udang vaname. Penelitian dilaksanakan pada bulan Desember 2018 Januari 2019 di Balai Karantina Ikan, Pengendalian Mutu, dan Keamanan Hasil Perikanan Surabaya I. Materi yang digunakan pada penelitian yaitu 37 sampel post larva. Sampel diekstraksi menggunakan Silica Extraction Kit kemudian dideteksi secara molekuler menggunakan PCR (Polymerase Chain Reaction). Penelitian ini bersifat observatif, selanjutnya data yang diperoleh dianalisis secara deskriptif. Hasil penelitian menunjukkan bahwa terdapat 3 sampel positif IMNV dan 2 sampel positif WSSV dengan nilai prevalensi sebesar 8,10\% dan 5,40\%. Tinggi rendahya nilai prevalensi dipengaruhi oleh tingkat penyebaran dan kondisi lingkungan yang kurang sesuai.
\end{abstract}

Keyword : PCR (Polymerase Chain Reaction), Prevalensi, Udang vaname, Virus.

\begin{abstract}
Pacific white shrimp has several advantages, namely rapid growth, able to adapt to a high range of salinity, and can be cultured with a super intensive system, but in recent years the total shrimp production in Indonesia has decreased. In 2012 the total shrimp production decreased from 1.900 tons to 1.025 tons, the virus is thought to be a pathogen that triggers disease in shrimp and causes high mortality. The purpose of this study is to detect viruses that infected and determine the prevalence of viruses that attack pacific white shrimp. The research was conducted in December 2018 to January 2019 at Fish Quarantine Center, Quality Control and Security of Fishery Product Surabaya I. The material used in the study was 37 post larval samples. Samples extracted using Silica Extraction Kit, then detected molecularly using PCR (Polymerase Chain Reaction). This research was observational, then the data obtained were analyzed descriptively. The results showed that there were 3 positive samples of IMNV and 2 positive samples of WSSV with prevalence values of $8.10 \%$ and $5.40 \%$. High and low prevalence values are influenced by the level of virus spread and inappropriate environmental conditions.
\end{abstract}

Keyword : Pacific white shrimp, PCR (Polymerase Chain Reaction), Prevalence, Virus. 


\section{PENDAHULUAN}

Udang vaname (Litopenaeus vannamei) merupakan salah satu komoditas perikanan unggulan yang bernilai ekonomis penting dan banyak diminati oleh konsumen di pasaran. Berdasarkan data International Trade Center (2017), kontribusi nilai ekspor udang vaname terhadap total nilai ekspor perikanan tahun 2016 mencapai lebih dari $27 \%$. Kegiatan budidaya udang vaname sudah dikomersilkan dan berkembang pesat di berbagai daerah sehingga pembudidaya udang vaname semakin meningkat (Haliman dan Adijaya, 2006).

Total produksi udang mengalami penurunan pada tahun 2012 dari 1.900 ton menjadi $1.025,8$ ton (Arafani dkk, 2016). Virus diduga menjadi patogen yang memicu penyakit pada udang. Jenis virus yang menyebabkan kerugian pada budidaya udang vaname adalah Taura Syndrome Virus (TSV), Infectious Myonecrosis Virus (IMNV), White Spot Syndrome Virus (WSSV), virus tersebut mengganggu pertumbuhan meliputi bentuk tubuh yang tidak normal, ukuran benih yang tidak seragam, pertumbuhan yang lambat, hingga menyebabkan kematian pada kegiatan budidaya (Balai Budidaya Laut Lampung, 2011).

Pengujian virus perlu dilakukan sebelum udang didistribusikan antar wilayah dalam negeri maupun kegiatan ekspor dan impor, hal ini bertujuan untuk meminimalisir penyebaran penyakit terutama yang disebabkan oleh virus pada udang vaname. Metode yang banyak digunakan untuk pengujian virus yaitu metode Polymerase Chain Reaction (PCR). Prinsip kerja dari metode tersebut adalah menggandakan fragmen DNA spesifik yang diinginkan dengan ukuran tertentu dengan mekanisme perubahan suhu (Fatimah dkk, 2010). Berdasarkan uraian-uraian di atas, maka perlu dilakukan Penelitian untuk mendeteksi virus yang menyerang udang vaname dan mengetahui tingkat prevalensi virus yang menyerang udang vaname.

\section{METODE PENELITIAN}

\section{Waktu dan Tempat}

Penelitian ini dilaksanakan pada bulan Desember 2018 - Januari 2019 di Balai Karantina Ikan, 
Pengendalian Mutu, dan Keamanan Hasil Perikanan Surabaya I.

\section{Alat dan Bahan}

Sampel udang vaname terdiri dari naupli, post larva, dan calon induk vaname berasal dari daerah Tuban dan Lamongan. Setiap sampel udang kemudian diekstrak DNA atau RNA nya. Kemudian diamplifikasi dan yang terakhir dielektrofresis.

Tahapan Ekstraksi DNA dan RNA Virus

Organ target diambil sebanyak 0,02 gram, organ target dimasukkan kedalam mikrotube kemudian digerus selanjutnya diekstraksi mengikuti prosedur yang telah ada. Poses ekstraksi DNA atau RNA dilakukan dengan menggunakan Silica Extraction Kit. Ekstraksi bertujuan untuk mendapatkan DNA atau RNA sampel dari organ targetnya (Fitriatin dan Abdul, 2015). Menurut Langga (2012) ada tiga tahap utama dalam ekstraksi materi genetik yaitu perusakan membran sel (lisis), pemisahan materi genetik dari bahan padat seperti protein, serta pemurnian materi genetik. Supernatan dipindahkan pada mikrotube baru sebanyak $200 \mu 1$.

\section{Amplifikasi}

Amplifikasi DNA atau RNA virus dilakukan pada kondisi PCR seperti predenaturasi $95^{\circ} \mathrm{C}$ selama 15 menit, denaturasi $94^{\circ} \mathrm{C}$ selama 30 detik, annealing $59^{\circ} \mathrm{C}$ selama 1 menit 30 detik, ekstension $72^{\circ} \mathrm{C}$ selama 1 menit 30 detik dan fi nal ekstension $72^{\circ} \mathrm{C}$ selama 10 menit, diulang sampai 35 siklus. Komposisi amplifikasi virus RNA dan DNA tersaji pada tabel 1 dan desain primer yang dipakai disajikan pada Tabel 2 . Reagen amplifikasi yang telah dibuat dimasukkan ke dalam mesin Thermal cycler $\left(\mathrm{T} 100^{\mathrm{TM}}\right)$ siklus yang terjadi pada saat amplifikasi dalam mesin thermal cycler.

Tabel 1. Komposisi Reagen Amplifikasi Deteksi Virus di Balai Karantina Ikan, Pengendalian Mutu, dan Keamanan Hasil Perikanan Surabaya I

\begin{tabular}{lcc}
\hline \multicolumn{1}{c}{ Komposisi } & $\begin{array}{c}\text { Virus } \\
\text { DNA }\end{array}$ & $\begin{array}{c}\text { Virus } \\
\text { RNA }\end{array}$ \\
\hline Master mix & $12,5 \mu \mathrm{l}$ & $12,5 \mu \mathrm{l}$ \\
NFW (DEPC & $7,5 \mu \mathrm{l}$ & $5,75 \mu \mathrm{l}$ \\
untuk RNA) & & \\
Primer F & $0,5 \mu \mathrm{l}$ & $1 \mu \mathrm{l}$ \\
Primer R & $0,5 \mu \mathrm{l}$ & $1 \mu \mathrm{l}$ \\
Inhibitor & - & $0,5 \mu \mathrm{l}$ \\
RT Enzym & - & $0,25 \mu \mathrm{l}$ \\
Template & $4 \mu \mathrm{l}$ & $4 \mu \mathrm{l}$ \\
\hline Total & $\mathbf{2 5 \mu l}$ & $\mathbf{2 5} \boldsymbol{\mu l}$ \\
\hline
\end{tabular}


Tabel 2. Primer Spesifik Yang Digunakan untuk Deteksi Virus pada Udang Vaname di Balai Karantina Ikan, Pengendalian Mutu, dan Keamanan Hasil Perikanan Surabaya I

\begin{tabular}{|c|c|c|}
\hline $\begin{array}{l}\text { Jenis } \\
\text { Virus }\end{array}$ & Sekuens Primer & $\begin{array}{l}\text { Ukuran } \\
\text { Amplikon }\end{array}$ \\
\hline \multirow[t]{2}{*}{ TSV } & Primer 9992F 5'-AAG-TAG-ACA-GCC-GCG-CTT-3' & \\
\hline & Primer 9195R 5'-TCA-ATG-AGA-GCT-TGG-TCC-3' & $321 \mathrm{bp}$ \\
\hline \multirow[t]{4}{*}{ IMNV } & Primer 4587F 5'- CGA-CGC-TGC-TAA-CCA-TAC-AA -3' & \\
\hline & Primer 4914R 5'- ACT-CGG-CTG-TTC-GAT-CAA-GT -3' & 139 bp \\
\hline & Primer 4725NF $5^{\mathrm{ee}}$ - GTA ACT GCC CCT TTC ACT TCC A $-3^{\mathrm{ee}}$ & \\
\hline & Primer 4863NR $5^{\mathrm{ee}}$ - TAC GGC AGC TGC TGC ACC TTG T $-3^{e e}$ & \\
\hline \multirow[t]{4}{*}{ WSSV } & Primer 146 F 5' - ACT ACT AAC TTC AGC CTA TCT AG - 3' & \\
\hline & $\begin{array}{l}\text { Primer } 146 \text { R } 5^{\text {ee }} \text { - TAA TGC GGG TGT AAT GTT CTT ACG A - }\end{array}$ & $941 \mathrm{bp}$ \\
\hline & Primer 146NF 5'- GTA-ACT-GCC-CCT-TCC-ATC-TCC-A -3' & \\
\hline & Primer 146NR 5'- TAC-GGC-AGC-TGC-TGC-ACC-TTG-T -3' & \\
\hline \multirow[t]{2}{*}{ IHHNV } & Primer 389F 5' - CGG-AAC-ACA-ACC-CGA-CTT-TA -3' & 389 bp \\
\hline & Primer 389R 5' - GGC CAA GAC CAA AAT ACG AA -3' & \\
\hline
\end{tabular}

Elektroforesis

Amplikon dielektroforesis pada gel agarose 2\% yang direndam dengan larutan GT buffer 1 kali. Gel agarose dialiri arus listrik dengan tegangan 120 volt selama 40 menit. Hasil elektroforesis selanjutnya didokumentasikan menggunakan alat yaitu UV Transluminator yang terhubung langsung dengan kamera dan laptop yang berfungsi sebagai penampil hasil dokumentasi. Ketika sinar UV dinyalakan maka band DNA sampel akan muncul dan berpendar.

\section{Parameter Pengamatan}

Parameter utama yang diamati yaitu prevalensi virus yang menyerang udang vaname, parameter pendukung yaitu melihat gejala klinis udang vaname sebelum dilakukan pemeriksaan. Sampel udang vaname yang positif terinfeksi virus kemudian dihitung dan dianalisa berdasarkan perhitungan matematik untuk mengetahui menilai prevalensi. Nilai prevalensi digunakan untuk mengetahui banyaknya udang yang terinfeksi virus. Prevalensi dapat dihitung menggunakan rumus menurut Cameron (2002).

Prevalensi $(\%)=\frac{\sum \text { udang terinfeksi }}{\sum \text { sampel udang }} \times 100 \%$

\section{Analisa Data}

Data yang diperoleh diolah menggunakan program Microsoft Excel 2003 kemudian dianalisis secara deskriptif untuk menjelaskan nilai prevalensi virus yang menginfeksi udang vaname berdasarkan referensi yang relevan

\section{HASIL DAN PEMBAHASAN}


Terdapat 46 sampel post larva udang vaname. Setelah dilakukan pengujian beberapa jenis virus menggunakan teknik PCR dengan menggunakan primer spesifik (Tabel 2) menunjukkan bahwa terdapat sampel yang positif terinfeksi virus. Dari data di atas didapatkan nilai prevalensi masingmasing virus yang diperiksa di Balai Karantina Ikan, Pengendalian Mutu, dengan tingkat prevalensi mencapai $8,10 \%$. Elovaara (2001) menyatakan bahwa, apabila nilai prevalensi di suatu wilayah kurang dari 50\% maka serangan virus di wilayah tersebut masih tergolong rendah sehingga dapat dinyatakan bahwa tingkat prevalensi virus WSSV dan IMNV pada udang vaname di wilayah tersebut masih pada tingkat yang relatif rendah.

\section{dan Keamanan Hasil Perikanan}

Stapabła Niilai Prevalensi Virus Pada udang vaname yang berasal dari Lamongan dan Tuban pada tanggal 17 Desember 2018 - 25 Januari 2019

\begin{tabular}{lcccc}
\hline Jenis Virus & $\begin{array}{c}\text { Jumlah Sampel } \\
\text { Positif }\end{array}$ & $\begin{array}{c}\text { Jumlah Sampel } \\
\text { Negatif }\end{array}$ & Total & Prevalensi \\
\hline TSV & 0 & 40 & 40 & $0 \%$ \\
IMNV & 3 & 34 & 37 & $8,10 \%$ \\
WSSV & 2 & 33 & 35 & $5,71 \%$ \\
IHHNV & 0 & 15 & 15 & $0 \%$ \\
\hline
\end{tabular}

Udang vaname (Litopenaeus

Berdasarkan hasil pengujian virus di Balai Krantina Ikan, Pengendalian Mutu, dan Keamanan Hasil Perikanan Surabaya I dapat diketahui nilai prevalensi virus yang menyerang stadia post larva udang vaname. Sampel udang vaname yang diperoleh dari beberapa tambak produktif di daerah Lamongan dan Tuban memiliki nilai prevalensi yaitu WSSV sebesar 5,71\%, IMNV $8,10 \%$, TSV 0\%, dan IHHNV 0\%.

Tingkat prevalensi tertinggi ditemukan pada jenis virus IMNV vannamei) lebih rentan terhadap infeksi golongan RNA virus TSV dan IMNV dan beberapa golongan DNA virus seperti WSSV dan IHHNV (OIE, 2006). Infeksi virus lain seperti YHV dan MBV pernah ditemukan namun tingkat infeksinya tidak seperti pada virus lainnya. Menurut

Koesharyani et al., (2012) infeksi virus MBV dan YHV lebih rentan menyerang udang windu (Penaeus monodon). Penyakit WSSV, dan IMNV yang terjadi di 
tambak salah satunya dapat disebabkan oleh benur udang yang telah terinfeksi di pembenihan karena induknya yang terinfeksi dan selanjutnya menimbulkan penyakit setelah dipelihara di tambak sebagaimana telah dilaporkan oleh Uma et al., (2005).

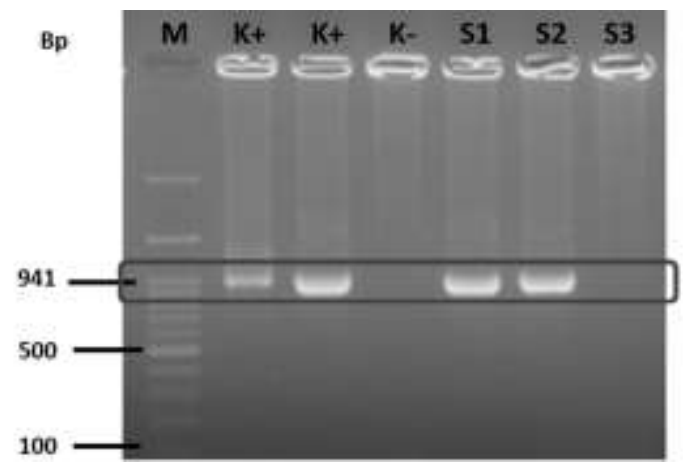

Gambar 1. Hasil Elektroforesis Produk PCR DNA WSSV di Balai Karantina Ikan, Pengendalian Mutu, dan Keamanan Hasil Perikanan Surabaya I (sumber: dokumentasi balai). Keterangan: $\mathrm{M}=$ marker; $\mathrm{K}+=$ kontrol positif; K- = kontrol negatif; S1-S3 = DNA Sampel.

\section{Berdasarkan}

hasil

pemeriksaan virus WSSV dengan metode PCR, sampel yang terinfeksi WSSV ditandai dengan munculnya band pada 941 bp (OIE, 2003). Gejala klinis udang yang terinfeksi WSSV yaitu nafsu makan menurun, tubuh kemerahan, berenang ke permukaan, aktivitas menurun, muncul bintik putih dan usus kosong, sedangkan pada udang yang sehat ciri-cirinya adalah warna tubuh biru atau kehijauan, bergerak aktif, nafsu makan normal, usus penuh dan hetopankreas berwarna coklat.

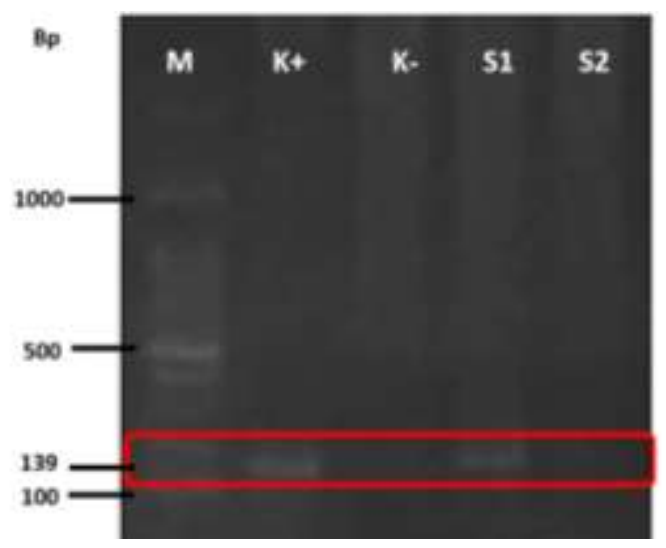

Gambar 2. Hasil Elektroforesis Produk PCR RNA IMNV di Balai Karantina Ikan, Pengendalian Mutu, dan Keamanan Hasil Perikanan Surabaya I (sumber: dokumentasi balai). Keterangan: $\mathrm{M}=$ marker; $\mathrm{K}+=$ kontrol positif; $\mathrm{K}-$ = kontrol negatif; $\mathrm{S} 1=$ DNA Sampel positif; S2 = DNA sampel positif.

Sarjito dan Desrina (2016) menyebutkan hasil nested RT-PCR pada udang vaname yang positif IMNV akan muncul pendaran band pada 139 bp. Infeksi IMNV dapat menyebabkan mortalitas mencapai 40\%-70\% (OIE, 2012). Infectious Myonecrosis Virus (IMNV) merupakan virus RNA, untai ganda, family Totaviridae, non envelope, berbentuk icosahedral dengan diameter virion $40 \mathrm{~nm}$ (Senapin et al., 2007). 


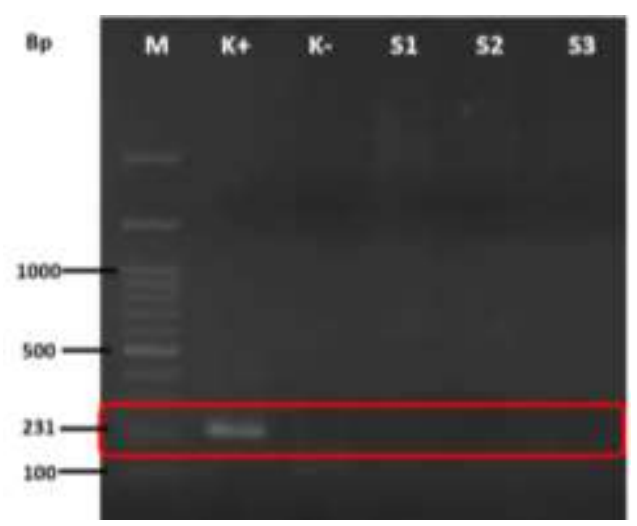

Gambar 3. Hasil Elektroforesis Produk PCR RNA TSV di Balai Karantina Ikan, Pengendalian Mutu, dan Keamanan Hasil Perikanan Surabaya I (sumber: dokumentasi balai). Keterangan: $\mathrm{M}=$ marker; $\mathrm{K}+=$ kontrol positif; K- = kontrol negatif; S1-S3 = DNA Sampel.

$$
\text { Berdasarkan hasil }
$$

pemeriksaan virus TSV dengan metode PCR, sampel yang diduga terinfeksi TSV ditandai dengan munculnya band pada 231 bp (Koesharyani dkk, 2012). . Gejala klinis udang yang terinfeksi TSV adalah kaki renang dan telson berwarna kemerahan serta adanya bintik hitam di sekitar tubuh.

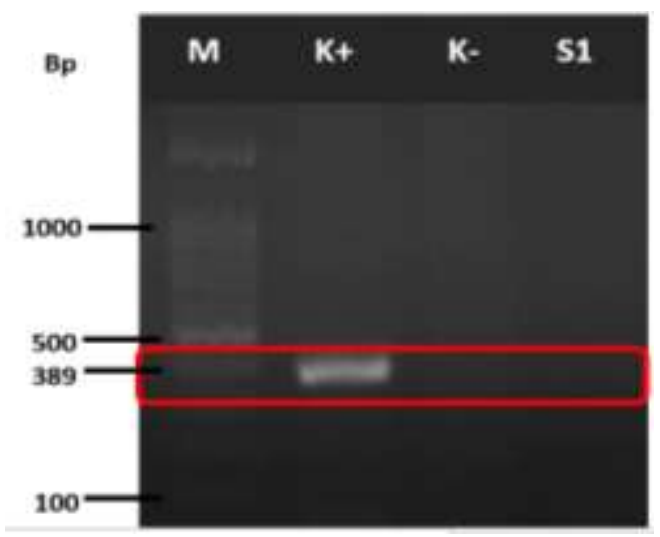

Gambar 4. Hasil Elektroforesis Produk PCR DNA IHHNV di Balai Karantina Ikan,
Pengendalian Mutu, dan Keamanan Hasil Perikanan Surabaya I (sumber: dokumentasi balai) Keterangan: $\mathrm{M}=$ marker; $\mathrm{K}+=$ kontrol positif; K- = kontrol negatif; $\mathrm{S} 1=$ DNA Sampel negatif.

Berdasarkan hasil pemeriksaan virus IHHNV dengan metode PCR, sampel yang diduga terinfeksi IHHNV ditandai dengan munculnya band pada 389 bp (Tang et al., 2007). Gejala klinis udang yang terinfeksi virus tersebut yaitu udang sering naik ke permukaan air, jarang bergerak dan sering berputarputar sebelum akhirnya tenggelam ke dasar tambak, kulit udang akan terlihat putih keruh dan rostum membengkok (Lightner et al., 1996)

\section{KESIMPULAN}

Jenis virus yang sering menginfeksi udang vaname yaitu Taura Syndrome Virus (TSV), Infectious Myonecrosis Virus (IMNV), White Spot Syndrome Virus (WSSV), Infetious Hypodermal and Haematopoetic Necrosis Virus (IHHNV), Yellow Head Virus (YHV) dan Monodon Baculovirus (MBV). Prevalensi virus TSV 0\%, IMNV $8,10 \%$, WSSV $5,71 \%$, dan IHHNV $0 \%$.

\section{DAFTAR PUSTAKA}

Arafani, L., M. Ghazali dan M. Ali. 2016. Pelacakan Virus Bercak Putih pada Udang Vaname (Litc 
Balai Budidaya Laut Lampung. 2011. Pengelolaan Kesehatan Ikan Budidaya Laut. Direktorat Jenderal Perikanan Budidaya, Departemen Kelautan dan Perikanan Jakarta.

Cameron, A. 2002. Survey Toolbox fo Aquatic Animal Diseases. Australian Centre for International Agricultural Research. Canberra. 373

Elovaara EK. 2001. Shrimp Farming Manual: Practical Technology For Intensive Shrimp Production. British West Indies: Carribean Press Ltd.

Fatimah, Urnemi, A. Z. Mustopa, dan H. Syahrumsyah. 2010. Aplikasi Marka Molekuler Pada Buah dan Biji Kopi Asal Kalimantan Timur. Berita Biologi. 13 (1).

Fitriatin E., dan Abdul M. 2015. Pemeriksaan Viral Nervous Necrosis (VNN) pada Ikan dengan Metode Polymerase Chain Reaction (PCR). Jurnal Ilmiah Perikanan dan Kelautan, 7 (2) : 149-152.

Haliman R W, Adijaya DS. 2006. Udang Vaname. Penebar Swadaya. Jakarta

Koesharyani, I., L. Gardenia, dan H. Supriyadi. 2012. Multi Infeksi pada Udang Litopenaeus vannamei : Diagnosis Dengan Polymerase Chain Reaction (PCR) dan Reverse Transcriptase-Polymerase Chain Reaction (RT-PCR). Jurnal Riset Akuakultur, 7 (1) : 73-84

Lightner, D. V. 1996. A Hand Book of Shrimp Pathology and Diagnostic Procedures for Disease of Culture Penaeid Shrimp Asia. World Aquaculture Society, Baton Rouge, L.A. USA.

Office International des Epizooties (OIE). 2003. Manual of Diagnostic Tests for Aquatik Animal. 4th Edition. Office International Des Epizooties. France. 285-297.

Office International des Epizooties. 2012. Manual of Diagnostic Tests for

Aquatic Animals. 4thed. OIDE. France. 554 p.

Sarjito, M.U. dan Desrina. 2016. Pengaruh Salinitas Terhadap Infeksi Infectious myonecrosis virus (IMNV) pada Udang Vaname (Litopenaeus vannamei). Journal of Aquaculture 